\title{
PENGARUH PENGGUNAAN KEKERANGAN SEBAGAI BIOFILTER TERHADAP KELIMPAHAN DAN KOMPOSISI JENIS BAKTERI PADA BUDIDAYA UDANG WINDU (Penaeus monodon) DENGAN SISTEM RESIRKULASI AIR
}

\author{
Muliani*), Muharijadi Atmomarsono*) dan Mun Imah Madeali ${ }^{*}$
}

\begin{abstract}
ABSTRAK
Penelitian ini bertujuan untuk melihat pengaruh penggunaan kekerangan terhadap komposisi jenis dan kelimpahan bakteri pada pemeliharaan udang windu (Penaeus monodon) dalam wadah dengan sistem resirkulasi air. Penelitian dilakukan di Laboratorium Balai Penelitian Perikanan Pantai, Maros dengan menggunakan serat kaca ukuran $1 \times 1 \mathrm{~m}^{2}$ sebanyak 11 buah. Udang windu ukuran pascalarva sebanyak 100 ind./bak sebagai hewan uji, serta kerang hijau (Perna viridis), tiram (Crassostrea iredalei) dan kerang bakau (Geloina coaxan) masing. masing sebanyak $250 \mathrm{~g}$ bobot daging sebagai biofilter ditebar secara terpisah. Untuk mengetahui pengaruh perlakuan terhadap komposisi jenis bakteri, data dianalisis secara deskriptif sedangkan kelimpahan bakteri dianalisis dengan menggunakan rancangan acak kelompok (RAK).

Hasil penelitian menunjukkan bahwa kandungan jumlah bakteri dalam wadah pemeliharaan terendah pada perlakuan yang menggunakan tiram sebagai biofilter, kemudian berturutturut kerang bakau, kerang hijau dan kontrol (U2<U3<U1<UK). Namun demikian hasil analisis statistik tidak menunjukkan perbedaan yang nyata $(\mathrm{P}>0,05)$ antar perlakuan. Hal ini menunjukkan bahwa air yang diresirkulasi kualitas mikrobiologisnya relatif sama dengan air laut baru. Hasil identifikasi terhadap komposisi jenis bakteri pada semua perlakuan relatif sama yaitu: Acinetobacter spp., Aeromonas spp., Bacillus spp., Enterobacteriaceae, Flavobacterium spp., Micrococcus spp., Pseudomonas spp., Staphylococcus spp. dan Vibrio spp.
\end{abstract}

ABSTRACT: Effect of different bivalves as biofilter on' total number and composition of bacteria in tiger prawn, Penaeus monodon culture using water recirculation system. By:Muliani, Muharijadi Atmomarsono and Mun Imah Madeali.

To see the effect of different bivalves as biofilter on total number and composition of bacteria in tiger prawn ( $\boldsymbol{P}$. monodon) culture using water recirculation system, the experiment was carried out at laboratory of the Research Institute for Coastal Fisheries (RICF) for eight weeks. Eleven fibreglasses of $1 \times 1 \mathrm{~m}^{2}$ fillet with about $200 \mathrm{~L}$ of sea water were used separately for holding tiger prawn (P. monodon) post larvae (100 ind./tank), bivalves ( $250 \mathrm{~g}$ life meat weight/tank) and sedimentation. Three different bivalves used separately as biofilter in water resirculation system were green mussel (Perna viridis), slipper oyster (Crassostrea iredalei) and mangrove clam (Geloina coaxan). Randomized blok design was applied in this experiment.

Results showed that total numbers of bacteria in tiger prawn culture using slipper oyster as biofilter were slightly lower than those using mangrove clam, green mussel and control $(U 2<U 3<U 1<U K)$, even though was no significant difference among the treatments $(P>0.05)$. This indicates that recirculated sea waters has similar microbiological quality with the new one. Composition of bacteria isolated from the tiger prawn culture tanks were the same in all treatments, ie. Acinetobacter spp., Aeromonas spp., Bacillus spp., Enterobacteriaceae, Flavobacterium spp., Micrococcus spp., Pseudomonas spp., Staphylococcus spp., dan Vibrio spp.

KEYWORDS: bivalves, biofilter, bacteria, tiger prawn, water recirculation.

\section{PENDAHULUAN}

Pengembangan usaha budidaya udang dari tahun ke tahun mengalami peningkatan, baik melalui perluasan areal pertambakan maupun intensifikasi. Konsekuensi dari peningkatan tersebut adalah menurunnya kualitas lingkungan yang berdampak pada timbulnya berbagai macam penyakit. Dengan sistem intensifikasi, masukan yang diberikan untuk meningkatkan produksi udang semakin tinggi, sedangkan pemberian pakan bila tidak dikontrol menjadi berlebih dapat

\footnotetext{
" Peneliti pada Balai Penelitian Perikanan Pantai, Maros
} 
menyebabkan penimbunan limbah bahan organik. Jika hal ini tidak dikelola dengan baik maka dapat memicu perkembangan mikroorganisme penyebab penyakit. Sedangkan dengan sistem ekstensifikasi sering dijumpai kendala, yaitu sulitnya melakukan pergantian air pada lokasi-lokasi yang jauh dari sumber air, sehingga tidak jarang air yang dimasukkan ke dalam tambak adalah air yang berasal dari saluran pembuangan yang belum sempat terdorong ke laut. Berdasarkan hal ini perlu dicari alternatif pemecahannya di antaranya melalui pengelolaan air secara resirkulasi.

Pengelolaan limbah budidaya udang telah banyak dilakukan di Thailand melalui sistem pengendapan air dengan menggunakan tandon. Sistem ini memiliki kekurangan karena memerlukan lahan yang luas, di mana sekitar $30 \%$ dari total area digunakan sebagai petak tandon (Chanratchakool et al., 1995). Cara lain yang telah dicoba untuk mengatasi limbah budidaya udang intensif adalah dengan menggunakan biofilter. Organisme yang digunakan sebagai biofilter antara lain mujair merah, bandeng dan kekerangan. Penggunaan organisme tersebut sebagai biofilter selain dimaksudkan untuk memperbaiki kualitas air, juga untuk menghemat areal yang digunakan dan menambah produksi hasil sampingan.

Beberapa jenis kerang yang dapat digunakan sebagai biofilter antara lain tiram, kerang hijau, kerang bangko, dan kerang bulu. Menurut Atmomarsono (1995), tiram mampu mengakumulasi logam berat $\mathrm{Pb}$ dan $\mathrm{Cu}$ dalam jumlah tinggi yaitu masing-masing $1185 \%$ dan $473 \%$ dari kandungan awalnya yaitu $0,013 \mathrm{mg} / \mathrm{L}$ dan $0,238 \mathrm{mg} / \mathrm{L}$. Kerang bakau mampu mengakumulasi $\mathrm{Zn}$ sebesar $431 \%$ dari kandungan awalnya $(0,515 \mathrm{mg} / \mathrm{L})$. Kekerangan selain mampu menyerap logam berat juga menyerap fitoplankton sebagai makanan (Amini et al., 1995; Amin et al., 1996; dan Parenrengi et al., 1996). Berdasarkan hal ini diduga kekerangan dapat digunakan sebagai biofilter bakteri pada budidaya udang windu. Keberadaan bakteri dalam suatu wadah budidaya udang dapat berasal dari lingkungan (air), pakan dan benur yang digunakan. Bakteri tersebut akan berkembang jika lingkungan semakin memburuk, terutama oleh penimbunan sisa pakan dan kotoran udang yang memacu peningkatan kandungan bahan organik dalam air. Jika hal ini dibiarkan, kadar bahan organik akan semakin tinggi dan akan lebih memacu perkembangan bakteri. Penelitian penggunaan kekerangan sebagai biofilter bakteri perlu dilakukan. Penelitian ini bertujuan untuk melihat efektivitas kekerangan sebagai biofilter bakteri pada budidaya udang windu dalam sistem resirkulasi air. Hasil penelitian diharapkan dapat berguna sebagai acuan dalam melakukan budidaya udang windu sistem resirkulasi air pada daerahdaerah yang pemasokan airnya sulit.

\section{BAHAN DAN METODE}

Penelitian dilakukan di Laboratorium Balai Penelitian Perikanan Pantai, Maros. Bak serat kaca ukuran $1 \times 1 \mathrm{~m}^{2}$ sebanyak 11 buah digunakan sebagai wadah pemeliharaan (tiga buah untuk pemeliharaan udang, tiga buah untuk bak biofilter dan empat buah untuk bak pengendapan). Masing-masing wadah diisi air laut yang bersalinitas 31.34 ppt sebanyak $200 \mathrm{~L}$. Wadah udang diisi pascalarva udang windu sebanyak 100 ind,/wadah. Bak biofilter masing-masing diisi kerang hijau (Perna viridis), tiram (Crassostrea iredalei) dan kerang bakau (Geloina coaxan) secara terpisah sebanyak $250 \mathrm{~g}$ bobot badan (bobot daging hidup). Bobot total kerang hidup yang ditebar diperhitungkan berdasarkan hasil penimbangan 40 individu per contoh kerang. Rancangan percobaan yang digunakan adalah rancangan acak kelompok (RAK) dengan waktu sampling (dua minggu sekali) sebagai ulangan. Adapun bagan sistem resirkulasi air pada penelitian ini dapat dilihat pada Gambar 1. Air dari bak pemeliharaan udang disifon dan ditampung dalam ember/ baskom, kemudian air tersebut diganti dengan air yang berasal dari bak biofilter. Selanjutnya air dari bak pemeliharaan dimasukkan ke dalam bak biofilter. Volume air yang diresirkulasi sebanyak $10 \%$ yang dilakukan tiga hari sekali pada empat minggu pertama dan dua hari sekali pada empat minggu berikutnya. Sementara pada perlakuan kontrol (tanpa biofilter), air dari bak pemeliharaan langsung dibuang dan diganti dengan air baru yang berasal dari bak penampungan air laut.

Pengamatan jenis dan jumlah bakteri dilakukan dua minggu sekali. Isolasi bakteri dari air dalam bak pemeliharaan, biofilter dan pengendapan dilakukan dengan menggunakan dua macam media yaitu TSA (Triptic Soy Agar) dan TCBSA (Thiosulphate Citrate Bile Sucrose Agar). Jumlah bakteri dihitung dengan metode "Total Viable Count" (Austine, 1978). Jenis bakteri ditentukan dengan uji karakterisasi dan uji biokimia sesuai dengan cara Lewis (1973), Cowan dan Steel (Cowan, 1974), Sindermann \& Lightner (1988) 


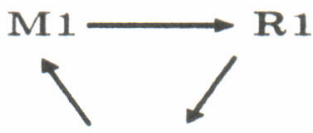

U 1

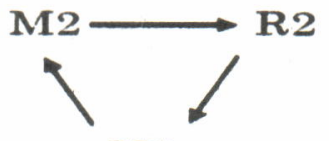

U2

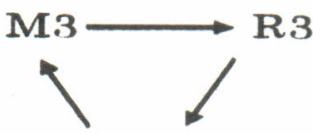

U3

Keternngan (Note):

M1 = lak biofilter kernng hijan (250 g bolsot tulouh/1 1 $1 \mathrm{~m}^{2}$ bak) green mussel biofilter tank (250 g body weight/tank of $\left.1 . x 1 \mathrm{~m}^{2}\right)$

M2 = liak biofilter tiram (250 g lobot tuluhl/ $1 \times 1 \mathrm{~m}^{2}$ bak) slipper ayster biofilter tank $\left(250 \mathrm{~g}\right.$ body weight/tank of $\left.|x| \mathrm{m}^{2}\right)$

M:s = bak biofilter kerang bakan (250 g lolbot tubuh/ $1 \times 1 \mathrm{~m}^{2}$ bak) mangrone clam biofiller tank (250 g body weight/tank of $|x| \mathrm{m}^{2}$ )

U1.U3 = lak pemeliharaan udang pasealarva (100 g bobot tubuh/1 $\times 1 \mathrm{~m}^{2}$ bak) culture tank containing tiger prawn post larvae (100 ind./tank of $\left.1 \times 1 \mathrm{~m}^{2}\right)$

(KK = bak kontrol udang pasenlarva (100 g bobot tubuh/ $1 \times 1 \mathrm{~m}^{2}$ bak) culture tonk containing control tiger prawn post larvae (100 ind, /tank of $\left.1 \times 1 \mathrm{~m}^{2}\right)$

$\mathrm{R} 1-\mathrm{R}: 3=$ hak reservoir berisi nir yang teluh disirkulasi (reservoir tanks containing recirculated water)

RK = bak penampungan berisi nir laut baru untuk perlakuan kontrol (reservoir tank containing new sea water for control treatment)

Gambar 1. Sistem resirkulasi air yang terdiri atas bak biofilter, pengendapan dan pemeliharaan udang.

Figure 1. Water recirculation system containing biofilter, reservoir and tiger prawn culture tanks.

dengan menggunakan media TSA miring, $\mathrm{O} / \mathrm{F}$, SIM, TSIA, MR.VP, King A, King B, Gelatin, dan Urea broth. Pengaruh penggunaan kekerangan sebagai biofilter terhadap komposisi jenis bakteri dianalisis secara deskriptif. Sedangkan perbedaan kelimpahan bakteri antar perlakuan dianalisis dengan sidik ragam yang dilanjutkan dengan uji beda nyata terkecil (BNT).

\section{HASIL DAN PEMBAHASAN}

Hasil penelitian menunjukkan bahwa dengan menggunakan kekerangan sebagai biofilter, kandungan bakteri cenderung menurun dan semakin menurun lagi setelah diendapkan pada bak pengendapan atau reservoir. Secara statistik terlihat adanya penurunan yang nyata $(\mathrm{P}<0,05)$ antara jumlah bakteri yang didapatkan dalam bak pemeliharaan udang (U) dan dalam bak biofilter (M) maupun bak pengendapan atau reservoir ( $\mathrm{U} 1>\mathrm{M} 1>\mathrm{R} 1, \mathrm{U} 2>\mathrm{M} 2>\mathrm{R} 2, \mathrm{U}>3 \mathrm{M} 3>\mathrm{R} 3$ ) (Tabel 1 ). Hal ini menunjukkan bahwa ketiga jenis kerang yang digunakan dalam penelitian ini (tiram, kerang hijau dan kerang bakau) mampu menurunkan populasi bakteri yang ada dalam air media. Dengan demikian, makin lama air tersebut berada dalam bak biofilter, maka populasi bakterinya yang masuk ke dalam bak pengendapan makin menurun. Oleh karena itu populasi bakteri dalam air di bak pengendapan (penampungan) menjadi lebih rendah dari pada di bak filter. karena air di bak pengendapan $(\mathrm{R})$ adalah berasal dari bak filter (M) yang berisi kekerangan. Jadi air ini dapat digunakan kembali untuk mengganti air yang telah mengandung banyak bakteri di bak pemeliharaan udang $(U)$.

Hasil penelitian juga menunjukkan bahwa jumlah total bakteri dalam air media pemeliharaan udang windu yang menggunakan biofilter tiram $\left(104,4 \times 10^{2} \mathrm{CFU} / \mathrm{mL}\right)$ adalah lebih rendah dari pada dalam air yang menggunakan biofilter kerang bakau ( $\left.113,1 \times 10^{2} \mathrm{CFU} / \mathrm{mL}\right)$, kerang hijau $\left(128,2 \times 10^{*} \mathrm{CFU} / \mathrm{mL}\right)$, ataupun kontrol yang meng. gunakan air laut baru $\left(210,3 \times 10^{2} \mathrm{CFU} / \mathrm{mL}\right)$, walaupun secara statistik tidak berbeda nyata $(P>0,05)$ antar perlakuan tersebut (Tabel 1). Sedangkan jumlah total bakteri dalam air laut baru $\left(0,5 \times 10^{2}\right.$ CFU/mL) adalah relatif lebih rendah dari pada dalam air di bak penampungan air yang telah diresirkulasi melalui bak biofilter tiram $\left(9,0 \times 10^{-}\right.$

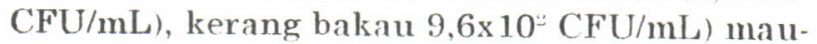
pun kerang hijau $\left(11,3 \times 10^{2} \mathrm{CFU} / \mathrm{mL}\right)$. Namun demikian hasil uji statistik juga memperlihatkan perbedaan yang tidak nyata $(\mathrm{P}>0,05)$ antar perlakuan tersebut, yang berarti bahwa ketiga jenis kerang tersebut dapat digunakan sebagai biofilter bakteri pada budidaya udang windu sistem resirkulasi, karena secara mikrobiologis kualitas airnya tidak berbeda dengan air laut baru. Amin et al. (1996) dan Parenrengi et al. (1996), mendapatkan daya serap tiram terhadap fitoplankton 
Tabel 1. Rata-rata jumlah total bakteri dalam bak pemeliharaan udang, bak biofilter, dan bak pengendapan selama dua bulan.

Table 1. Average number of bacteria in tiger prawn culture, biofilter and reservoir tanks during two-month culture period.

\begin{tabular}{|c|c|}
\hline $\begin{array}{l}\text { Perlakuan } \\
\text { Treatment }\end{array}$ & $\begin{array}{l}\left.\text { Jumlah total bakteri }\left(x 10^{2} \mathrm{CPU} / \mathrm{mL}\right)^{*}\right) \\
\text { Total number of bacteria }\left(x 10^{2} \mathrm{CFU} / \mathrm{mL}\right)\end{array}$ \\
\hline U1 & $128.2^{\mathrm{a}} \pm 53.2$ \\
\hline M1 & $36.1^{b} \pm 10.2$ \\
\hline $\mathrm{R} 1$ & $11.3^{\mathrm{c}} \pm 4.4$ \\
\hline U2 & $104.4^{\mathrm{a}} \pm 46.6$ \\
\hline M2 & $37.2^{b} \pm 10.7$ \\
\hline $\mathrm{R} 2$ & $9.0^{c} \pm 5.2$ \\
\hline U3 & $113.1^{\mathrm{a}} \pm 51.0$ \\
\hline M3 & $50.0^{\mathrm{b}} \pm 30.0$ \\
\hline R3 & $9.6^{\mathrm{c}} \pm 4.2$ \\
\hline TK & $210.3^{a} \pm 98.3$ \\
\hline RK & $0.5^{\mathrm{c}} \pm 0.2$ \\
\hline
\end{tabular}

adalah lebih tinggi dibandingkan kerang hijau, kerang bulu dan kerang bangko. Tingginya daya serap tiram diduga karena frekuensi bukaan cangkangnya saat penyerapan relatif lebih tinggi dibandingkan kerang hijau dan kerang bakau.

Hasil identifikasi terhadap jenis bakteri pada pemeliharaan udang windu ( $P$. monodon) dalam wadah percobaan dengan sistem resirkulasi air dengan menggunakan biofilter kerang hijau, tiram, dan kerang bakau didapatkan sembilan jenis bakteri (Tabel 2). Pada tabel tersebut terlihat bahwa jenis bakteri pada semua perlakuan relatif sama selama penelitian. Jumlah bakteri tersebut lebih tinggi dibanding yang didapatkan pada air sumber pada awal penelitian yaitu Pseudomonas spp., Acinetobacter spp., Bacillus spp., dan Flavobacterium spp. Peningkatan jumlah komposisi jenis bakteri yang ditemukan diduga berasal dari benur, pakan dan kekerangan yang digunakan. Suwidah (1995) menemukan beberapa jenis kerang yang terkontaminasi oleh bakteri. Keberadaan bakteri dalam tubuh kekerangan disebabkan karena sifat biologis kekerangan itu sendiri sebagai filter feeder. Meskipun jumlah jenis bakteri yang ditemukan selama penelitian lebih tinggi dibanding dengan jumlah awal sebelum ada perlakuan, hal ini tidak membahayakan karena tidak ditemukan dominansi yang berarti dari satu jenis tertentu. Menurut Atmomarsono et al. (1993a), bakteri akan membahayakan jika terjadi dominansi dari suatu jenis tertentu yang jumlahnya melewati ambang batas yang membahayakan.

Dari sembilan jenis bakteri yang ditemukan, dua di antaranya termasuk bakteri yang patogen oportunistik terhadap udang windu, yaitu Aeromonas spp. dan Vibrio spp. Jenis bakteri ini sering menimbulkan kematian udang baik di panti pembenihan maupun di tambak (Anderson et al., 1988; Lightner, 1988; Liu, 1989, Lavilla-Pitogo et al., 1992; Lightner et al., 1992; Nash et al., 1992; Boer et al., 1993; Atmomarsono et al., 1993a; Madeali et al., 1993; dan Rukyani, 1993). Selain kedua jenis bakteri tersebut, bakteri Enterobacteriaceae juga telah ditemukan menyebabkan kematian pada udang windu di tambak Kabupaten Pinrang (Atmomarsono et al., 1993b). Bakteri oportunistik seperti Vibrio spp. dan Aeromonas spp. umumnya ditemukan di perairan laut dan pantai, bahkan di dalam saluran pencernaan udang itu sendiri. Bakteri ini akan 
Tabel 2. Jenis bakteri yang ditemukan dalam air media udang selama dua bulan.

Table 2. Bacteria found in the water of rearing tank during two-month culture period.

\begin{tabular}{|c|c|c|c|c|c|c|c|c|c|c|c|}
\hline \multirow{2}{*}{$\begin{array}{c}\text { Jenis bakteri } \\
\text { Kind of bacteria }\end{array}$} & \multicolumn{11}{|c|}{ Bak pemeliharaan (Culture tank) } \\
\hline & $\mathbf{U 1}$ & $\mathbf{M 1}$ & $\mathbf{R 1}$ & U2 & $\mathbf{M 2}$ & $\mathbf{R 2}$ & Us & $\mathbf{M 8}$ & $\mathbf{R 3}$ & UK & $\mathbf{P}$ \\
\hline Acinetobacter spp. & + & + & + & + & + & + & + & + & + & + & + \\
\hline Aeromonas spp. & + & + & + & + & + & + & + & + & + & + & - \\
\hline Bacillus spp. & + & $\cdot$ & $\cdot$ & + & - & - & - & - & - & + & + \\
\hline Enterobacteriaceae & + & + & - & + & + & + & - & + & - & + & - \\
\hline Flavobacterium spp. & + & + & + & + & + & + & + & - & - & + & + \\
\hline Micrococcus spp. & + & - & - & + & + & + & + & - & - & + & - \\
\hline Pseudomonas spp. & + & + & + & + & + & + & + & + & + & + & + \\
\hline Staphylococcus spp. & + & + & + & + & + & + & + & + & + & + & - \\
\hline Vibrio spp. & + & + & + & + & + & + & + & + & + & + & - \\
\hline
\end{tabular}

Catatan (Note): $\quad+=$ ada (present)

. = tidak ada (absent)

berkembang dan menjadi patogen jika terjadi penurunan mutu air akibat penumpukan bahan organik yang berasal dari pakan dan kotoran udang.

Persentase jenis bakteri yang ditemukan dalam air media pemeliharaan udang selama penelitian untuk masing-masing perlakuan disajikan pada Gambar 2, 3, 4, dan 5 .

Dari Gambar 2, 3, 4, dan 5 terlihat bahwa jenis bakteri yang mendominasi semua perlakuan adalah Acinetobacter spp. Jenis bakteri ini merupa kan jenis bakteri yang paling umum ditemukan di perairan dan dianggap tidak membahayakan. Tidak adanya penurunan komposisi jenis bakteri pada penelitian ini disebabkan dalam tubuh kekerangan itu sendiri sudah terdapat bakteri. Hal ini sejalan dengan pendapat Valt (1972 dalam Morton, 1983), bahwa salah satu kesulitan dalam pengukuran laju penyaringan moluska terhadap bakteri atau partikel suspensi adalah adanya kemungkinan masuknya bakteri atau partikel suspensi itu sendiri.

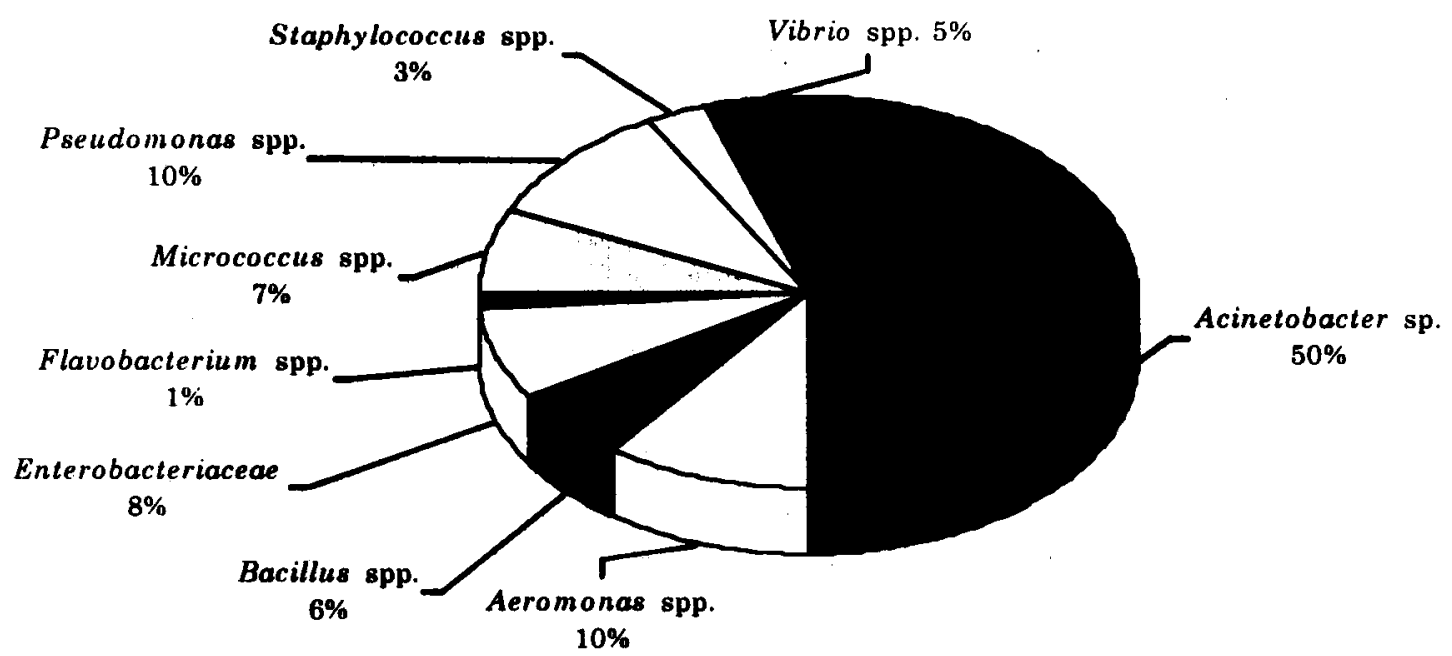

Gambar 2. Komposisi jenis bakteri yang diisolasi dari air media pemeliharaan udang pada perlakuan kerang hijau sebagai biofilter dalam sistem resirkulasi air

Figure 2. Composition of bacteria isolated from tiger prawn culture media using green mussel (Perna viridis) as biofilter treatment in water recirculation system. 


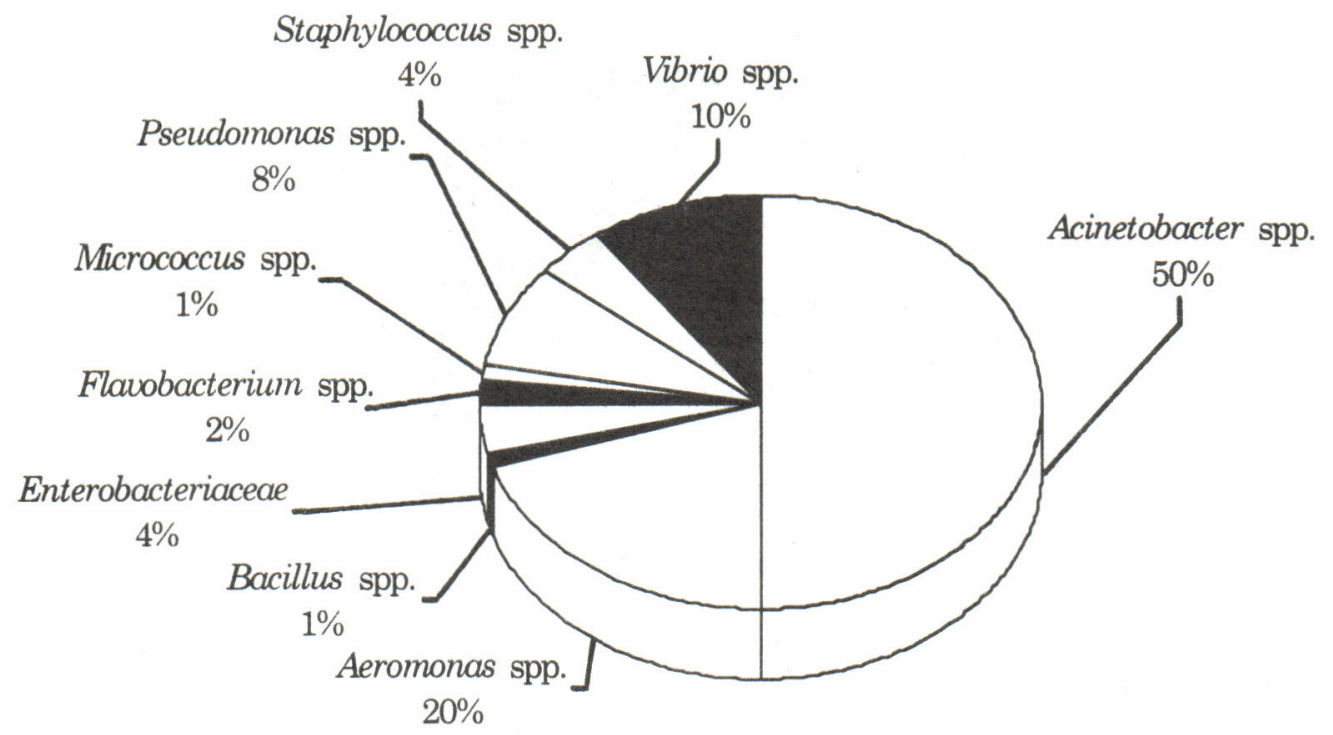

Gambar 3. Komposisi jenis bakteri yang diisolasi dari air media pemeliharaan udang pada perlakuan tiram sebagai biofilter dalam sistem resirkulasi air.

Figure 3. Composition of bacteria isolated from tiger prawn culture media using slipper oyster (Crassostrea iredalei) as biofilter in water recirculation system.

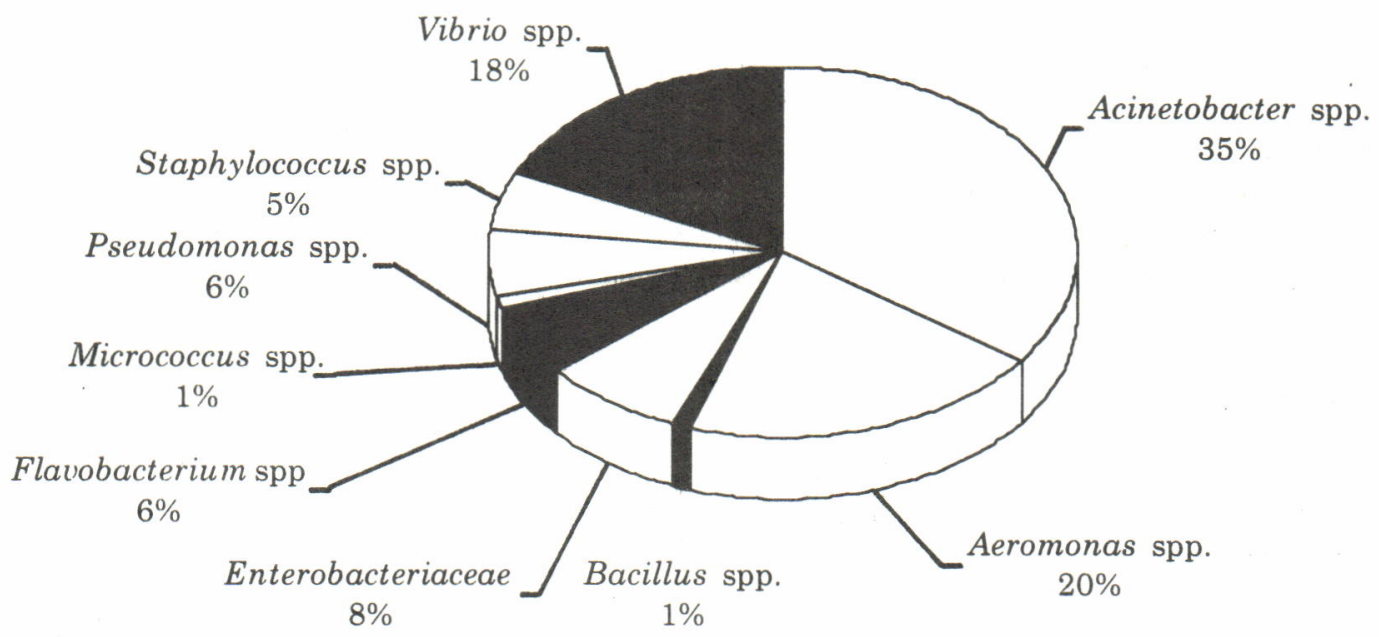

Gambar 4. Komposisi jenis bakteri yang diisolasi dari air media pemeliharaan udang pada perlakuan kerang bakau sebagai biofilter dalam sistem resirkulasi air.

Figure 4. Composition of bacteria isolated from tiger prawn culture media using mangrove clam (Geloina coaxan) as biofilter in water recirculation system. 


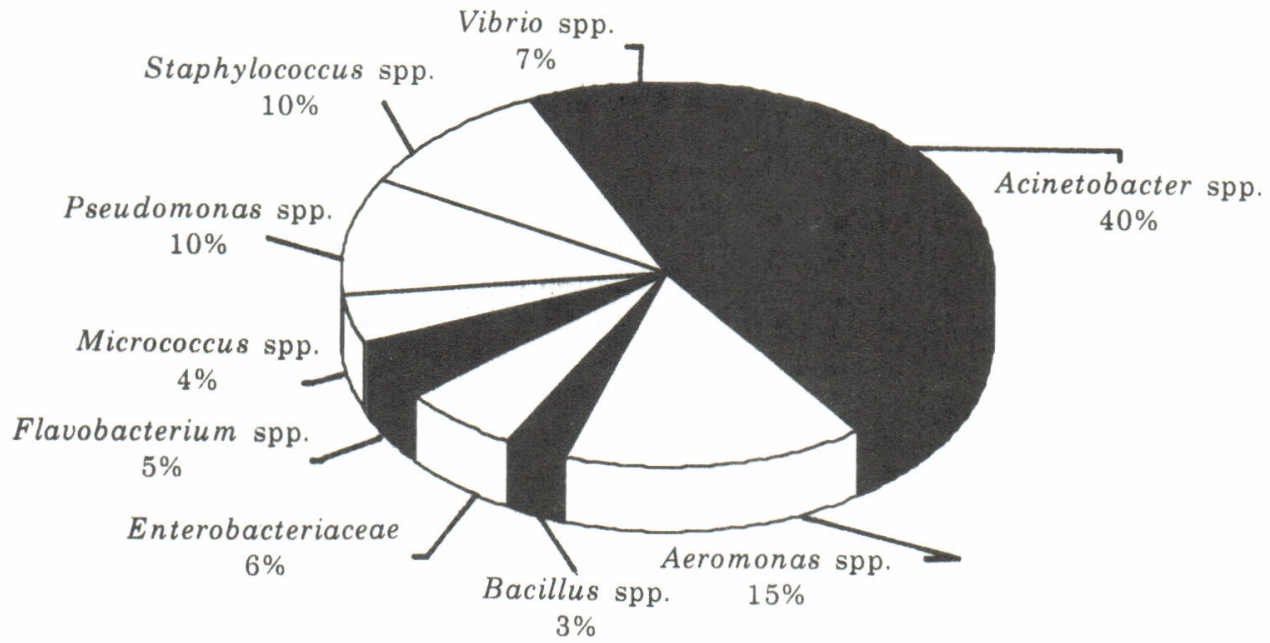

Gambar 5.Komposisi jenis bakteri yang diisolasi dari air media pemeliharaan udang pada perlakuan tanpa biofilter (kontrol).

Figure 5. Composition of bacteria isolated from tiger prawn culture media without biofilter (control).

Hasil analisis baik secara statistik maupun diskriptif menunjukkan bahwa penggunaan kekerangan sebagai biofilter tidak dapat menekan komposisi jenis bakteri akan tetapi dapat menekan jumlah populasi bakteri secara umum.

\section{KESIMPULAN}

1. Kandungan bakteri pada media budidaya udang windu yang menggunakan biofilter tiram lebih rendah daripada kerang bakau, kerang hijau dan kontrol, walaupun secara statistik berbeda tidak nyata $(\mathrm{P}>0,05)$.

2. Penggunaan kekerangan sebagai biofilter pada budidaya udang sistem resirkulasi tidak dapat menekan komposisi jenis bakteri, tetapi menurunkan jumlah populasi bakteri di mana jumlah bakteri dalam bak biofilter lebih rendah $(\mathrm{P}<0,05)$ daripada dalam bak pemeliharaan udang.

\section{UCAPAN TERIMA KASIH}

Penulis mengucapkan banyak terima kasih kepada Sdri. Nurjanna dan Indolette yang telah membantu dalam pelaksanaan penelitian ini.

\section{DAFTAR PUSTAKA}

Amin, M., A. Parenrengi dan Dalfiah. 1996. Daya serap kekerangan terhadap Chaetoceros spp. dalam bak terkontrol. Laporan Hasil Penelitian. Balai Penelitian Perikanan Pantai Maros. Belum dipublikasikan. 6 hal.
Amini, S., M. Amin, A. Parenrengi dan R. Pasande. 1995. Kekerangan sebagai biofilter fitoplankton skala laboratorium. Laporan Hasil Penelitian. Balai Penelitian Perikanan Pantai Maros. 24 hal.

Anderson, I.G., M.N. Shamsuddin, M. Shariff, and G. Nash. 1988. Bacterial septicemia in juvenile tiger prawn, Penaeus monodon, cultured in Malaysian brackishwater ponds. Asian Fisheries Science 2:93. 108.

Atmomarsono, M. 1995. Penggunaan moluska sebagai biofilter pada pemeliharaan udang windu. Laporan Hasil Penelitian, Balai Penelitian Perikanan Budidaya Pantai, Maros. 15 hal (tidak dipublikasikan).

Atmomarsono, M., M. I. Madeali, A. Tompo, dan Muliani. 1993a. Bakteri penyebab penyakit pada udang windu di perairan tambak Sulawesi Selatan. Makalah dibawakan pada Simposium Perikanan I, Jakarta, 25-27 Agustus 1993. 9 hal.

Atmomarsono, M., M.I. Madeali, Muliani dan A. Tompo. 1993b. Kasus penyakit udang windu di Kabupaten Pinrang. Dalam Hanafi, A., M. Atmomarsono, dan S. Ismawati. Prosiding Seminar Hasil Penelitian Perikanan Budidaya Pantai, Maros 16-19 Juli 1993. 35-40

Austine, B. 1987b. Marine Microbiology. Cambridge Univeristy Press. Cambridge. 222 pp.

Boer, D. R., Zafran and T. Ahmad. 1993. Penanggulangan penyakit udang windu (Penaeus monodon) di panti benih. Dalam Hanafi, A., M. Atmomarsono, dan S.Ismawati (Eds.), Prosiding Seminar Hasil Penelitian Perikanan Budidaya Pantai, Maros. 16-19 Juli 1993. 9-12.

Chanratchakool, P., J. F. Turnbull, C. Limsuwan, and S. F. Smith, 1995. Third Shrimp Health Manage- 
ment. Training Hand-Book. The Aquatic Animal Health Research Institute. Department of Fisheries. Kasetsart University Campus. Bangkok.

Cowan, S. T. 1974. Cowan and Steel's Manual for the Identification of Medical Bacteria, $2^{\text {nd }}$ edition. Cam. bridge University Press. Cambridge.

Lavilla-Pitogo, C.R., L.J. Albright, M. G. Paner, and N. A. Sunaz. 1992. Studies on the sources of Luminescent Vibrio harveyi in Penaeus monodon hatcheries. In Sharrif. I. M., R.P. Subasinghe, and J.R Arthur (Eds.) Diseases in Asian Aquaculture. Fish Health Section, AFS, Manila, Philippines. 157-164.

Lewis. D. 1973. Predominant aerobic bacteria of fish and shellfish. Texas $A$ and $M$ University, Sea Grant College, Texas, USA. In Sindermann, C.J. and D.V. Lightner (Eds.). Disease Diagnosis and control in North American Marine Aquaculture. Elsevier. Amsterdam.

Lightner, D.V. 1988. Vibrio disease of peneid shrimp. Fish Section, AFS, Manila, Philippines. 42-47.

Lightner, D.V., T.A. Bell, R.M. Redman, L.L. Mohley, J.M. Natividad, A. Rukyani. and A. Poernomo. 1992. A review of some major disease of economic signifi. cant on penaeid prawns/shrimp of the Americans and Indopacific. In Shariff, I. M.., R.P. Subasinghe, and R.J. Arthur (Eds.), Diseases in Asian Aquaculture. Fish Health Section, Asian Fisheries Society, Manila. Philippines. 57.80.

Liu. Cheng.I. 1989. Shrimp diseases, prevention and treatment. In Akiyama, D.M. (Ed.), Proceeding of the Southeast Asia Shrimp Farm Management Workshop. Republic of Singapore. 64-74.

Madeali, M.I., M. Atmomarsono, A. Tompo, dan Muliani. 1993. Studi kasus penyebab kematian udang windu. Penaeus monodon di tambak intensif. J. Penelitian Budidaya Pantai, 9(4): 23-28.

Morton, B. 1983 Feeding and digestion in bivalvia. In Saleuddin, A.S.A, and K.M. Wilbur (Eds.), The Mollusca. Vol. 5. Academic Press. A. Subsidiary of Harcourt Brace Novanovich. Publisher. New York. Paris. San Diego. Sanfransisco. Sao Paulo. Sydney. Tokyo. Toronto. 65-147.

Nash, G., C. Nithimathackoke, C. Tungmandi, A. Arkarjamorn, P. Prathampipat, and $P$. Ruamthaveesud. 1992. Vibriosis and its control in pond-reared Penaeus monodon in Thailand. In Shariff, I. N., R.P. Subasinghe, and R.J. Arthur (Eds.), Diseases in Asian Aquaculture. Fish Health Section, AFS, Manila. Philippines. 143-155.

Parenrengi, A. A.M. Pirzan, Muliani, M. Amin, dan Dalfiah. 1996. Penggunaan beberapa jenis molluska sebagai biofilter fitoplankton pada air tambak udang di laboratorium. Laporan Hasil Penelitian. Balai Penelitian Perikanan Pantai. 9 hal.

Rukyani, A. 1993. Penanggulangan penyakit udang windu, Penaeus monodon. Dalam Hanafi, A., M. Atmomarsono, dan S. Ismawati. Prosiding Seminar Hasil Penelitian Perikanan Budidaya Pantai, Maros 16-19 Juli 1993. 1-8.

Sindermann, C.J. and D.V. Lightner. 1988. Diseases Diagnosis and Control in North American Marine Culture, Second (revised) Edition. Elsevier Scientific Publishing Co., Amsterdam, Oxford, New York. $431 \mathrm{pp}$.

Suwidah. 1995. Pemantauan bakteri patogen pada kerang di perairan Teluk Pare-Pare, Sulawesi Selatan. Tesis. Program Pascasarjana. Universitas Hasanuddin. Ujung Pandang. 79 hal. 